\title{
LEARNING MODEL OF HOSPITAL CLINICAL PRACTICE FROM STUDENT AND CLINICAL EDUCATOR POINT OF VIEW: A QUALITATIVE STUDY
}

\author{
(Model Pembelajaran Praktik Profesi Ners dari Sudut Pandang Mahasiswa dan \\ Pembimbing Klinik: Penelitian Kualitatif)
}

\author{
Ni Putu Kamaryati, Ni Luh Putu Dina Susanti ${ }^{2}$, dan Anak Agung Ayu Yuliati Darmini ${ }^{3}$ \\ Sekolah Tinggi Ilmu Kesehatan (STIKES) Bali, Indonesia \\ E-mail: kamaryati.stikesbali@gmail.com
}

\begin{abstract}
ABSTRAK
Pendaluan: Pendidikan yang berkualitas dicirikan dengan proses belajar dan mengajarnya yang berkualitas baik di kelas, laboratorium maupun praktek klinik. Menghasilkan lulusan perawat yang dapat memberikan asuhan keperawatan yang rofesional kepada pasien dibutuhkan pembelajaran praktek yang menggunakan model pembelajaran yang tepat. Tujuan dari penelitian ini adalah untuk mengeksplorasi pengalaman dan harapan mahasiswa dan pembimbing klinik tentang model pembelajaran praktek profesi ners. Metode: Penelitian ini menggunakan desain kualitatif dengan pendekatan phenomenologi. Delapan partisipan yang meliputi mahasiswa dan pembimbing klinik dilibatkan dalam penelitian ini secara purposif . Data dikumpulkan dengan tehnik wawancara mendalam. Kemudian data ditranskipsikan dan dianalisa menggunakan analisis tematik. Hasil: Hasil penelitian menemukan terdapat lima tema yang berhubungan dengan pengalaman dan harapan mahasiswa dan pembimbing klinik tentang model pembelajaran klinik. Tema tersebut meliputi dukungan institusi dan tempat praktek, Bed Side Teaching (BST), konferen, waktu pembimbing yang kurang, dan case study. BST, konferen dan case study merupakan beberapa model pembelajaran yang dilaksanakan saat praktek klinik. Metode ini akan dapat berjalan dengan baik jika ada dukungan dan supervisi yang baik. Diskusi: BST, konferen, dan case study merupakan metode pembelajaran yang cocok untuk praktek klinik. Kurangnya waktu pembimbing adalah salah satu hambatan yang ditemukan. Hal ini sangat penting bagi pembimbing klinik meluangkan waktu yang cukup dalam membimbing mahasiswa dalam praktek klinik.
\end{abstract}

Kata Kunci: pengalaman, harapan, mahasiswa, pembimbing klinik, model pembelajaran praktek

\begin{abstract}
Introduction: Qualified education is characterized by qualified teaching and learning in the classroom, laboratory, and clinical practice. Producing nurses who are able to provide professional nursing care for patients requires learning process in practice by using learning models. The purpose of this study was to explore the experience and expectation of students and clinical instructors on practices learning model in Ners Program of STIKES Bali. Method: This study used qualitative design with phenomenology approach. There were 8 participants from students and clinical instructors selected by purposive sampling. Data were collected by in-depth interviews. Data were transcribed and analyzed using thematic analyses. Results: Findings indicated that there were five themes related to a student and clinical instructor's experience and expectation about practices learning model. The themes were supporting from institution and clinic, bed side teaching (BST), conference, lack of time of clinical instructor in supervising, and case study. BST, conference, and case study were some of the learning models implemented in clinical practices. These methods will run properly if there are good supporting and optimal supervising. Discussion: BST, conference, and case study are appropriate methods for clinical teaching. Lack of time in supervising is one of the barriers found. It is essential for clinical instructors to spend sufficient time to supervise students in clinical practice.
\end{abstract}

Keywords: experience, expectation, student, clinical instructor, practices learning model

\section{INTRODUCTION}

Qualified education is characterized by the quality of teaching and learning in the classroom, laboratory and clinical practice. The aim of the learning process in the classroom is to enhance student's knowledge to deliver good nursing care. Whereas, in clinical practice is to improve student's skills in providing nursing care. These goals are related to the higher nursing education of Indonesia's goal. It is to produce nurses who are able to provide professional nursing services to patients (Karim \& Utomo, 2014). For achieving the goal, every institution should provide opportunities for students to apply their knowledge in the clinical practice. It is needed to apply practices learning models 
to give experiences for students in managing proper health care.

The practices learning models used in clinical teaching are conferences, bed side teaching (BST), demonstration, and case study. These methods have benefits and disadvantages. The conference focuses on group discussion about the patient case which is started with pre conference post conference (Nursalam, 2007). BST is a method of small discussion with patient and students. In the BST method, a number of participants are limited (5 to 6 participants) which is pre conference and post-conference conducted in front of the patient. This method is a method usually used after demonstration proceed. Before performing this method required physical preparation, the psychology of students and tutors (Nursalam \& Efendi, 2009).

Based on the literature reviewed, Ekawati (2010) found that written clinical assignment was the largest contribution (38.64\%) on the level of student satisfaction in the nursing clinical learning experience. Conference contributed to the second level of student satisfaction (31.46\%). Implementation of BST was the smallest contribution $(21.70 \%)$ on the level of student satisfaction. In addition, Maysarah (2014) stated that there were in average level (43.3\%), good level (26.7\%) and poor level (30\%). Furthermore, for BST, there were $46.7 \%$ had an average level, $20 \%$ had a good level, and $33.3 \%$ had a poor level. A preliminary study conducted in March 2016, from 10 students who took ners program, there were 7 students preferred BST and others liked conference, demonstration, and nursing rounds.

According to previous studies, there were a lot of studies focused on quantitative study (Aryanty \& Uladari, 2013; Yusiana and Damayanti, 2013). but a limited study on qualitative research. While qualitative research can provide information subjectively from participants' itself (Kamaryati, Susanti, and Suyasa, 2015). Therefore, this study is necessary to conduct for contributing to education development especially on Ners Program to produce graduates who are competent and competitive in national and international level. The aim of this study is to explore the experiences and expectations of students and clinical instructor of practices learning model in Ners Program at STIKES Bali.

\section{METHOD}

This study used a qualitative method with a phenomenological approach. There were 8 participants involved by purposive sampling. The participants consisted of 5 students and 3 clinical instructors. The inclusion criteria were STIKES Bali students who are taking ners program, willing to be participants in the study by completing the informed consent. Whereas, clinical instructors (CI) were lecturers or practitioners in a clinical setting.

\section{Procedure and Research Etick}

This study is approved by ethic committee. Furthermore, researchers contacted potential participants. Potential participants were given an explanation of the research, goals, and procedures of the study. After they had understood all of the information, they were asked to sign a consent form. This study conducted at STIKES Bali and hospitals on June to July 2016. The study used in-depth interviewed method by using the list of questions that have been created by researchers. Confidentiality of the participants is considerable concern in the study.

Data were analyzed to explore experience and expectation's students and clinical instructors on practices learning models. Code of participants was created and transcribed the data from recorder manually. After finishing transcription, data analyzed to find themes.

\section{RESULT}

After analyzing and tracing themes, the study identified five themes, 1) Supporting from institution and clinic, 2) BST, 3) Conference, 4) Lack of time in supervising, 5) Case Study. 


\section{Supporting from institution and clinic}

Supporting from institution and clinic are very benefit in encouraging and giving students the opportunity to practice in ners program. It can be seen in the following statements:

"Dukungannya sudah sangat bagus buk ya....dengan memberikan dosen-dosen yang kompeten di bidangnya... terimakasih telah memberikan kita arahan dan bimbingan, sehingga kita bisa melewaati ini semua...eee alat dan sarana prasarana juga mendukung yaa, e.. kalo misalnya kita sedang ujian kan juga kekurangan alat di rumah sakit, kampus menyediakan, jdi kampus memberi dukungan, udah bagus kok buk... enggak.. enggak adaa...." (M.01)

"Dukungan ada..dukungan itu dah.. ee...disana banyak fasilitasnya ya.. kemudian beragai macam pasien kita dapat temukan disana.. berbagai macam penyakit kita dapat temukan...kita dapat belajar banyak tentang penyakit itu... ee.. dan macam-macam kita dapat pelajari... pembimbing juga mendukung kita...sama seperti diskusi, selesai kita membuat lapora keperawatan kita diskusikan apa sih gimana pasiennya, apa yang sudah diberikan ke pasien berupa asuhan kemudian tentang penyakit tersebut apa sih yang paling tepat kita beri.. kalo tidak diketahui diberi tahu dengan baik oleh pembimbing sana..."(M.02)

"eee..sebagian besar RS sudah punya ruangan untuk biimbingan....kalau di ICU disiapin ruangannya untuk pembelajaran atau meeting tapi di ICCU ndak ada.. Untuk pelaksanaan model pembelajaran ini....kalau tidak ada ruangan khusus yang disediakan namun kita kondisikan sesuai dengan ruangan namun masih bisa jalan model pembelajaran ini. Kebanyakan para ka. Ruangan sudah mendukung kegiatan ini ...." (M.04)

Clinical Instructors also stated the same things to support professional practice, it can be seen in the following statements:

"Kalau dari rumah sakit sendiri...kami welcome kok dengan mahasiswa yang akan praktek..kami erusaha membantu adik-adik semuanya untuk mendapatkan target-target yang harus dipenuhi. Dari pihak RS juga sudah berusaha menyediakan sarana dan prasarana yang dibutuhkan oleh mahasiswanya...apalagi rumahsakit kami adalah $R S$ pendidikan yang memang diperuntukkan bagi mahasiswamahasiswa perawat untuk melatih dirinya dan skill mereka" (C 01)

"Okay, e... bentuk dari pihak rumah sakit ya, em.. yang pertama dari orientasi menyediakan ruangan jadi itu salah satu bentuk dukungan dari segi sarana dan prasarana jadi kemudian mereka juga sudah menunjuk CI-CI yang kompeten yang bisa membimbing mahasiswa sehingga bisa membantu mahasiwa mencapai target kompetensi, kemudian dari fasilitas yanglain jika mahasiswa membutuhkan sesuatu di ruangan mereka juga sering memberikan isalnya contoh alat perawatan luka, peralatan injeksi dan lain sebagainya disamping memang melebihi kapasitas mereka kita yang harus atau mahasiswa yang menyediakan" (D. 02)

\section{Bed Side Teaching (BST)}

BST is one learning model in clinical practice for students. Participants expressed that BST was easier to understand. So students can learn directly, it can be seen in the following statements:

"Emm... bedsite teaching ya..karena kita sambil praktek didampingi oleh dosen, misalnya alat yang kurang bisa dikasik tahu, apa yang kita tidak ketahui bisa kita tanyakan. gitu" (M.02)

"Yang paling nyaman itu adalah bedsite teaching karena kan kita langsung ke pasien sama dosen jadi.. kita melakukan tindakan invasifke pasien, HE dan segala macam setelah itu dosen bisa langsung mengevaluasi, jadi kita bisa tahu salahnya itu dimana..."(M.01)

Clinical Instructors also stated the same things to support professional practice, it can be seen in the following statements:

"Bedsite teaching kelebihannya adalah mahasiswa bisa e.. istilahnya melihat secara langsung contoh misalnya bagaimana cara melakukan pengkajian pada pasien yang mengalami gagal jantung... jadi disini peran pembimbing itu. sangat penting bagaimana caranya mencontohkan secara riil kepada 
mahasiswa bahwa oh ini loh step-stepnya mulai dari e.. misalnya inspeksi palpasi perkusi auskultasi untuk menemukan apa sih kelainan-kelainan yang ada pada diri pasien, nah kekurangan dari bedsite teaching ini adalah persiapan antaraaa mahasiswa dosen dan pasien yang terkendala disini... karena di bedsite teaching disini power dari seorang pembimbing lebih ditonjolkan" (D.02)

"Untuk BST misalnya kelebihannya itu bagus e... ketrampilan spesifik dia misalnya memandikan, memasang infus, pegkajian, saya rasa tidak ada kelemahannya itu, kelemahannya paling kita perlu bagaimana cara kita pendekatan kepada pasien kalo misalnya BST kita lakukan kan minimal 2 orang yang satu pendidik yang satu mahasiswa jadinya minta ijin dulu ke pasien tapi selama ini sih tidak ada hambatan"

"ee... saya rasa pendekatannya enggak pas gitu ya... karena semuanya memiliki keunggulan dan kekurangan jadi gk bisa kita grade kan... jadi tergantung tujuan dari bimbingan kepada mahasiswa.. ee. Ya kayak tadi kalo misalnya mau ketrampilan klinik spesifik pilihannya adalah BST" (D.01)

"Sejauh ini.....saya lebih banyak menggunakan kombinasi dari keempat metode bimbingan yang ada.....tapi paling sering she BST...karena langsung bisa lihat dan bombing pasien di pasien langsung"(C.01)

\section{Conference}

Students expressed that conference is one model of learning in the practice in ners program. That can be seen in the following statements:

"Yang selama ini? Model pembelajaran yang disukai? Kalo yang pertama masuk kestase awal itu kan ada pre conference.. awal sebelum kita masuk itu kita harus cari apa yang apa isinya.. kan LP udah tahu mestinya kita apa yang akan kita cari.. ada.. pasti ada.. itu dah menerapkan dari teori yang ada di kampus... iya..." (M.03)

"ee.. model prakteknya itu...ya.. semacam diskusi dan confren dengan pembimbing.. apa yang kami tidak ketahui akan kami sampaikan kepada pembimbing.. pembimbing akan memberikan solusi tentang apa yang ditanyakan...iya pembimbing klinik dan kampus.. iyaa... semua welcome..."(M.02)

In addition, other statements came from clinical instructors, as bellow:

"conference ee. Pre dan responsi itu bagus untuk kognitifnya mahasiswa bagus untuk penekanan attitude..ee... akan tetapi kurang bisa mengarahkan skill mahasiswa biasanya hambatannya di ada atau tidaknya ruang yang representatif untuk bisa melakukan proses conference tersebut... sudah itu aja.."(D.01)

"Okay, e.. untuk.. e apa namanya?... e model pembelajaran ya? ...okay khususnya untuk kita membimbing dilapangan, menggunakan teknik pre conference dimana itu adalah pengawalan mahasiswa sebelum mereka menyentuh pasien atau sebelum melakukan perawatan kepada pasien" (D.02)

"Kalo conference kita biasanya gunakan saat diawal rotasi dan saat response kasus akhir sambil menanyakan target yang sudah didapatkan oleh mahasiswa atau yang belum didapatkan.conference itu juga sebagai tambahannya ..kalau ini dihilangkan tidak bisa juga..karena ini metodenya saling mendukung,.." (C.01)

\section{Case study}

One of the methods that are considered in learning practice process. This is expressed in the following statements:

"Kalo menurut tiang nggih...dari beberapa model nike tiang lebih condong ke study case...tolong lebih ditekankan itu... karena dari sana bisa mengetahui apakah benar teori yang didapatkan itu sudah sesuai dengan kenyataannya...kadang-kadang banyak ditemukan bahwa di teori...belum tentu sama dengan yang ada dikenyataannya..." (M.05)

"ee.. berjalan cuman case studi aja yang blom jadi kita kan gk bisa bahas kasusnya itu fokus karena kan satu kelompok jadi wkatu dosen juga terbatas jadi kalo misalnya mau case studi lebih banyak aja dikasi waktu .. e jadi kalo misalnya kita ketemu kasus baru cuma dibahas pengertian patofisiologi dan sedikit tentang itu jadi lebih banyak lebih banyakkk selain bedsite teaching lebih banyak 
case studi ... jadi biar buat askep itu gak siasia" (M.01)

Clinical Instructors also stated the same things to support professional practice, it can be seen in the following statements:

"kalo case studi bagus, malah ini teknik yang bagus dilakukan jadi case studi ini bisa dilakukan berbarengan dengan bedsite teaching.. jadi e... misalnya mahasiswa ingin mempelajari tentang kasus apa, kemudian e... kita bersama mahasiswa bersama-sama ke pasien untuk menunjukkan langkah yang benar kemudian cara memcahkan masalah yang benar atau problem solving mungkin tepatnya ya... e... kepada mahasiswa jadi mereka tahu secara nyata sehingga dia tidak membayangkannya saja tapi langsung praktek...’(D.02)

\section{Lack of time in supervising}

The other important thing is the time of clinical instructors in supervising of students. These some statements:

"Kekurangannya... mungkin untuk kita diskusi bersama itu, waktunya kita tidak lebih banyak, mungkin karena e... kita praktek ya namanya juga kalo pas praktek itu dosennya 2 kali dateng..saya harap sih dosennya bisa dateng 3 kali... iya.. tapi rata-rata sekali.. mungkin karena kesibukanya dosen gitu... yang.. yang sepert bu adi.. maaf bu ya...ee.. gak ada itu aja.. ada sih pak putu tapi karena sibuk ya.. iya..."(M.02)

"Emm.. kalo harapan saya dari profesi ners ini saya harap.. sudah berjalan bagus kok bu selama setahun ini metodenya sudah bener. manajemennya juga sudah bener... yang perlu ditingkatkan adalah bimbinganya... ada bapak ibu dosen yang bimbingannya jarang... eee. Bedsite teachingnya juga jarang lebih sering pre conference atau pas terakhir-terakhir itu buk...eem... ee kami sudah melaksanakan bu cuma pas pembimbingnya dateng pasiennya udah pulang.. enggak.. soalnya pas dosen dateng kita udah selesai ke pasien.. iya, pas kita melakukan tindakan...iya" (M.03)
The clinical instructors also said the same thing, it can be seen in the following statements:

"seorang pembimbing akademik untuk ke lapangan karena pengalaman saya agak sulit menyediakan waktu untuk dapat ke lapangan apa namanya agar satu shift bisa mendampingi mahasiswa jadi menemukan waktu yang tepat barang kali antara ee... waktu yang tepat bagisesuai dengan kondisi klinik agar bisa menemukan kasus yang representatif yang dipelajari mahasiswa itu perlu sebuah pendekatan yang baik itu..." (D.01)

"Kalau kekurangannya..ya kadangkadang kesiapan dari sarana dan fasilitas masing-masing ruangan serta timing atau waktu kita juga...kalau mau mempraktekkan yang seideal mungkin haruslah waktu yang disediakan lebih banyak...itu biasanya kita kendala di lapangan. Namun hal itu bisa disiasati dengan kontrak waktu dulu denganpasien dan mahasiswanya" (C.01)

\section{DISCUSSION}

Institution and clinical practice support are needed in the learning process on ners program. Good support from both sides will give good impact as well for students or learners who are implementing clinical practices. The research found that the support provided by the institution was very good. It is proved by some of the participants (M.01 and M.02) stated that "... provide competent lecturers in their expertise, ... if there were a lack of equipment in the clinical setting, institution provided it ... ". On the other hand, good support was provided by the hospital. Some participants (M.04, D.02, and C.01) said that "... the hospital already had a room for practicing some models, ... equipment is provided, ... CIs were competent, ... help get target...". This maybe the educational institutions and hospitals already have a joint commitment to applying some models of clinical learning. Without good support from the hospital as a provider of the learning 
environment in the clinic, students can not practice the models of learning acquired during their academic education. Henderson et al. (2011) stated that the clinical learning environment is very important because students not only practice the skills alone, but students learn about practical norms in providing nursing care.

BST is a learning model that provides opportunities for students to deal directly with patients (Nuzulianva, Diniyah, and Herfanda, 2015). Most participants said that BST was the most learning model applied to ners program. The reason is when the BST is done, various aspects of learning can be applied, for example, knowledge, communication, and the ability of clinical skills. The same is conveyed by Nuzuliana et al. (2015), BST was an appropriate method to be able to practice skills for clinical aspects, communication, and ethical.

The other of learning models in clinical practice is a conference. This method is often used when management practices in hospitals (Permatasari, Suryani, and Wulandari, 2014). The method gives a good learning experience for students in which students are prepared first before going clinical setting. After completing the practice, they can make an evaluation of all activities based on the achieved goals. The participants also expressed the same things both on pre and post conference. It may lead students to gain experience in clinical practice.

A case study is a clinical method of learning. This model has been developed by educational institutions to develop students' ability for enhancing their critical thinking. When interviewing some participants, they said that the case study focused on training and developing the critical thinking of students in different cases. This method can also increase student confidence in managing patients or cases especially to analyze and solve the problems (Permana, Sumarwati, and Setiyani, 2016). Even though, this method will be better to apply when it's implementation is combined with other methods. The same statements came from Nielsen et al. (2013), they stated that learning process by using case study could improve good attitudes, skills, and communication in interacting with the patient. The creativity of students in a clinical setting was the main point in improving problemsolving for students (Chan, 2012).

Implementation of teaching models in clinical practice is strongly influenced by the supervising role. This study found that lack of time in supervising from clinical instructors both from the institution and clinical practice. Some participants stated that it was difficult to meet with two of clinical instructors in the same time. This is possibly due to the workload. High workload gives impact in meeting with students. This could be an obstacle in implementing models of learning in ners program

\section{CONCLUSION}

Based on the findings and discussion can be concluded that some models of practical learning such as BST, Conference and case study are very suitable conduct in the ners program. However, this process will run smoothly if there was good support from the institution (STIKES Bali) and student practice environment. But one obstacle that was found in the study is a lack of time of clinical instructors to supervise the students. Therefore, it is expected for the clinical instructor to provide adequate time to supervise students. (PDPI 2011; Notoatmodjo 2003)

\section{REFERENCES}

Aryanty, N dan Ulandari, A. 2013. Persepsi Mahasiswa Terhadap Tahap Persiapan Bedside TeachingPada Pembelajaran Rotasi Klinik. JMJ, Vol. 1 No. 1. Hal. 45-50.

Burns, N. dan S.K. Grove. 2009. The Practice of Nursing Research: Appraisal, Synthesis, and Generation of Evidence, $6^{\text {th }}$ ed. Elsevier Inc., United State America.

Chan, Z. C.Y. 2012. A systematic review of creative thinking/creativity in nursing education. Nurse Education Today, XXX 
Ekawati, H. 2010. Hubungan Antara Persepsi Penerapan Metode Bimbingan Klinik dengan Tingkat Kepuasan Mahasiswa dalam Pengalaman Belajar Klinik di RSUD Dr. Soegiri Lamongan. Tesis.

Henderson,A., Cooke, M., Creedy,D.K., dan Walker,R. 2011. Nursing students's perceptions of learning in practice environments: a review. Nurse Education Today, 32.

Kamaryati, N. P., Susanti, N. L. P., \& Suyasa, I. G. P. D. (2015). Pengalaman lansia dengan inkontinensia fekal di Kota Denpasar, Bali. Jurnal Kesehatan Caring and Enthusiasm, 4(1), 86-96.

Maysarah. 2010. Hubungan antara bimbingan klinik dengan metode konferensi dan bedside teachingdengan tingkat kepuasan mahasiswa praktik di RSUD Sragen. Sumber: http://perpusnwu.web. id/karyailmiah/ documents/3653.pdf. Diakses tanggal 14 April 2016.

Moleong, L.J.. (2002). Metodologi penelitian kualitatif. Bandung: PT Remaja Rosdakarya.

Nielsen, A.E., Noone, J., Voss,H., dan Mathews, L.R. 2013. Preparing nursing students for the future: an innovative approach to clinical education. Nurse Education in Practice, XXX. p. 1-9.

Nursalam, N. 2007. Manajemen keperawatan: Aplikasi dalam praktek keperawatan profesional. Jakarta: Salemba Medika
Nursalam, N dan Effendi, F. 2009. Pendidikan dalam Keperawatan. Jakarata: Salemba Medika

Nuzuliana, R., Diniyah,K. dan Herfanda,E. 2015. Gambaran pelaksanaan bed side teaching pada praktik klinik kebidanan jenjang Diploma III Stikes 'Aisyiyah Yogyakarta. Jurnal Kebidanan dan Keperawatan, Vol. 11., No.2

Permana, R.H., Sumarwati, M., dan Setiyani, R. 2016. Model Standardized Patient Experience (SPE) dalam melatih kemampuan berpikir kritis pada mahasiswa keperawatan dibandingkan dengan case study. Jurnal INJEC, Vol. 1, No. 1.

Permatasari, D. Suryani,M. Dan Wulandari. 2014. Efektifitas post conference terhadap operan sif di Ruang Rawat Inap RSUD Ungaran. Akses tanggal 1 oktober 2016. Sumber: http://download. portalgaruda.org/article. php?article $=3$ $93145 \& \mathrm{val}=6378 \&$ title $=$ EFEKTIFITA S\%20POST\%20CONFERENCE\%20 TER HA DA P \% 20 OPER AN $\% 20$ S I F \% 20 D I \% 20 R U A N G \% 20 RAWAT \%20INAP\%20RSUD\%20 UNGARAN

Yusiana, M.A dan Damayanti, N.A. 2013. Evaluasi Penerapan Pembelajaran klinik Keperawatan MetodeBedside Teaching dan Penugasan Klinik Berdasarkan Evaluasi CIPP. J. Adm. Kebijak. Kesehat. Vol. 11, N0. 2, Hal. 80-83. 